\title{
9. What has native title done to the urban Koori in New South Wales who is also a traditional custodian?
}

\section{Dennis Foley}

\begin{abstract}
Native title is a concept in the law of Australia that recognises the continued ownership of land by local Indigenous Australians ... it is also an example of two distinct systems of law operating within the same geographic, national and jurisdictional space ... however, to the extent of any inconsistency between Australian law and customary Aboriginal law, non-indigenous rights will generally prevail (Wikipedia 2007).
\end{abstract}

The Wikipedia definition of native title seems straightforward; non-indigenous rights prevail and native title recognises Aboriginal ownership of land-or does it? What does native title mean to the urban Koori who is born, raised and educated on their customary lands now called Sydney? These same lands are now occupied by some 4.2 million people who are representative of settler society. The Sydney population also includes a large number of growing Indigenous groups who are not the descendants of traditional owners. Rather the majority of Indigenous Australians in the specific example of Sydney and its environs are themselves usurpers.

This is a paper on native title as it applies to Sydney: what native title is and what it isn't, how it has been adopted by the black usurper and white coloniser and used as a process to deny Traditional Owners a voice in their rightful lands. The denial process is entwined within the legislation that is the Land Rights Act No. 421983 (NSW) (LRA).

\section{Background to the New South Wales Land Rights Act}

In June 1983 the Wran Labor Government enacted the LRA, which subsequently allowed Aboriginal land councils to claim empty Crown land not needed for essential public purposes. This Act had its initiative in the early South Australian lands trust; in 1974 the New South Wales Coalition government had sponsored the establishment of a Lands Trust. The Trust's main activity was the purchasing of residential properties. In time it became the landlord to around 20 per cent of the State's Indigenous population. Much of this property later ended up as valuable assets for land councils and Aboriginal housing groups. The advent of the Wran Labor Government in 1976 was hailed as a necessary first step towards the granting of inalienable land rights to Indigenous people. After much delay and despite heated debate and opposition from some Indigenous groups, the 
parliament of New South Wales passed the LRA. It gave certain groups freehold title over current Aboriginal reserves but had no process for claiming former Aboriginal reserves. The only non-reserve land that could be claimed was Crown land that had no future use and was not being used. There was no recognition of traditional ownership (Bennett 1999: 104; Wilkie 1985).

Our traditional custodians were ill-prepared for what followed. Aboriginal Land Councils were established very quickly and began a land grab. This was often without any involvement or consent from local Aboriginal people who were direct descendants of the traditional people of the lands in question. Guringah people generally were still recovering from wearing the brunt of nearly 180 years of physical and psychological trauma (dating from the establishment of Sydney town adjacent to our lands in 1788 through to the 1967 referendum which removed discriminatory clauses from the Australian constitution). These traumas included firstly dispossession of our land, enforced segregation and discrimination, and then assimilation and the denial of our culture. Guringah people were not fully conversant with the new opportunities that the Act bestowed upon them, nor savvy enough about the workings of the new legal system. There was a lag in the granting of these opportunities and in local resolution as to how to respond to them. Another group of Indigenous people however stepped into the vacuum and took advantage of this significant historical event. We Guringah custodians could not believe other Aboriginal people could act against us to both deny our existence and then steal our traditional lands from under us. But they did and history will show that the medium to allow this was the LRA.

It is important to understand the overall ramifications of the 1983 Act for other Aboriginal people throughout New South Wales. The Wran government was not the benefactor to Aboriginal people by the enactment of the 1983 legislation with an offer of 6000 acres of land (a 'fund' together with the subsequent opportunity of claiming unwanted Crown lands) as some would suggest. Rather the Act was a smokescreen to cover what the government had realised in 1979, four years previously, when they and their legal advisors understood a legal ambiguity that had been created in 1913. For between 1913 and 1969 some 25000 acres of 'old reserves' in New South Wales had been confiscated, at times forcibly with the use of police firearms (Goodall 1988: 37). Many of these old reserve properties were productive farm lands, developed and managed with pride by enterprising Aboriginal families. In 1979 the Wran Government's legal people concluded that the Aboriginal Crown lands seized were in fact vested in the Protection and Welfare Boards until 1969, not the Lands Department as previously thought. Therefore in 1983 the freehold title over the old reserves was invalid and the Aboriginal people as the beneficiaries of the now defunct Directorate of Aboriginal Affairs could have had a successful claim on 25000 acres of land that was arguably theirs. Many firmly believed that the reserved 
land was decreed or granted to them by Queen Victoria in recognition of their traditional ownership (Goodall 1996: 376-8).

The Wran government would only pass the 1983 Act on the condition that Aboriginal people would not oppose a new parallel law; the Retrospective Validation of Revocations Act which enforces a conscious theft of title to some 25000 acres of Aboriginal land.

In 1988 the chairperson of the New South Wales Aboriginal Land Council defended their own actions in support of the introduction of the 1983 Act: '[L]ets face it - this is the only opportunity that we have had to implement self-management, self-determination and to give us the opportunity to establish an economic base; to give us the opportunity to be less of a burden to the taxpayers of this state.'

Honorable rhetoric, the outcomes of which in the Sydney example are anything but self-management, self-determination and the opportunity to establish an economic base, as is illustrated by observations made by two political journalists discussed later in this paper (Jopson and Ryle 2004).

It seems that native title issues under (British) Australian law in New South Wales results in a continuous passage of pain and discrimination for Aboriginal people. The key discussion point of this paper concerns the perceived or actual financial benefit that usurping Aboriginal groups have made under the 1983 Act which has in many ways protracted local Indigenous impoverishment and marginalisation. It also highlights the process of native title and how the beneficiaries of the Act (that is the NSW Aboriginal land councils) become cultural auditors for the federal native title legislation.

\section{Historical background}

The Sydney region has had a strange allure for Aboriginal people from further afield, from the time that smallpox first decimated our people in 1789. Some travelled to the burgeoning town for medical assistance, or for food, because many Indigenous people were starving. Some came because everything they knew or valued was disrupted during the early days of colonisation. Others came to trade or obtain the rum that seemed to soothe the confusion and pain of colonial cultural chaos. Others just watched from the periphery. The Guringah, Darug and southern clans tried as much as possible to stay away from the newly arrived visitors. But the British stayed and we struggled to maintain a sustainable existence.

By the 1880s small pockets of traditional owners and others continued to exist in various locations of Sydney. They included Manly, Neutral Bay, Double Bay, Blues' Point, the north shore of Botany Bay, La Perouse, Kurnell, Sans Souci and

\footnotetext{
1 Tiga Bayles, in Chalk 1988a).
} 
a noisy camp at Circular Quay (Nugent 2005: 47). Other settlements have been recorded at Pittwater, Narrabeen Lakes and in isolated pockets along the Hawkesbury and its tributaries (Brook 1999; Foley 2001). Darug families could still be found along the Hawkesbury, the Nepean and Colo Rivers, on the Sackville Reserve, near Rooty Hill, and in and around the various farms working on the western urban fringe (Goodall 1988: 35).

As early as the 1880s the housing developments around what would become the Enfield Rail yards provided small, low cost housing for people of 'colour'. Pockets of Koori families in rented housing were well established in the Glebe Point, Forest Lodge, Ultimo, Chippendale and Camperdown-Newtown areas as the inhabitants provided a reliable, cheap labour source for the stevedoring industry, and various merchants and factories which operated in the area. By the 1890s, Aboriginal families whose members worked on the railway began to concentrate around the 'block' area in Redfern. Numerous housing enclaves for railway workers were constructed in easy walking distance to the main rail workshop areas. Many of these workers were Aboriginal. By the early 1900s an increasingly diverse group of people (including southern Europeans, Indigenous Australians and Chinese) were well established in the tight narrow streets of the inner west. ${ }^{2}$ Published histories of Sydney, written between the late 19th century and the 1960s, have failed to account for the Aboriginal presence. After George Thornton was appointed Protector of Aborigines in 1881, he pursued a campaign to remove Aboriginal people from Sydney. He forcibly closed down the metropolitan Aboriginal camps and prohibited the provision of rations to city-dwelling Aboriginals (Nugent 2005: 50-7). Despite Thornton's attempts however, many Koori families were not dependent on welfare. They had access to employment; and rented, lived and continued to work on their traditional lands. These people managed ingeniously to stay outside the Protector's watch and reach. Their invisibility from the Protector is reflected in the public record, and their stories have been omitted from the historical landscape of Sydney (Nugent 2005: 54-7). This is not the time nor place for speculations as to whether this was an unconscious oversight or a strategic 'whitewashing' by historians however its occurrence is noteworthy.

The lure of jobs in Sydney during the Great Depression and the rural decline during the 1920s and 1930s saw an influx of Indigenous people from country areas. This precipitated a turning point in Indigenous affairs in Sydney as Indigenous peoples seeking to relocate from country New South Wales to the metropolitan area, increasingly outnumbered the small groups of surviving traditional custodians. In the 1950s and 1960s Eora peoples were provided with an opportunity to move to the outer Sydney fringe where inexpensive rental

2 Gordon Foley, pers. comm., c. 1970. 
accommodation was made available in new housing commission estates in the western suburbs. ${ }^{3}$ These included Chester Hill, Bass Hill, Regents Park, Yagoona, Cabramatta, Warwick Farm, Merrylands and a multitude of other postwar housing estates. Other impoverished inner city dwellers who could afford these rentals went with them seeking healthier living conditions. People of Koori, southern European and Anglo-Celtic backgrounds became mixed in the western sprawl. Those Eora peoples who preferred to remain in city camps or could not afford the rents, were rounded up by authorities and subsequently 'disappeared'. Their camps - including the well-known one at Narrabeen Lakes - were demolished. The whereabouts of many of these people remained forever unknown to other members of their families, many of whom were too afraid to ask questions. Shortly thereafter, the inner city area around Redfern became a magnet for Indigenous people from rural regions searching for employment or political activity similar to that led by Afro-American Martin Luther King in the United States (King's anti-segregation campaigns commenced in the mid 1950s). The combination of the two spatial flows of city and country Aboriginal groups (the westerly dispersal of traditional custodians from urban Sydney and the centralisation of rural arrivals towards Redfern), together with the emergence of a new generation of Aboriginal activists fired by the success of international events, had significant consequences for power relations between local and newly arrived Indigenous groups. This was a migration of Aboriginal people, the traditional owners of Sydney were dispersed, and the migrating Aboriginal people from Moree, Dubbo and Cowra (as examples) became the usurpers. This had serious implications for the traditional owners in subsequent generations.

During the early 1970s Indigenous people formerly from rural areas became increasingly vocal and active in community management. For example, the Federal Council for the Advancement of Aborigines and Torres Strait Islanders (FCAATSI) became an 'all black' institution. This trend towards Indigenous-only managed organisations continued to both strengthen and broaden in scope (Horner 2004). As previously mentioned by Bayles (1988) Aboriginal people saw land rights legislation as an opportunity. However, this opportunity was dominated by the usurping Indigenous groups.

Whilst the Eora voice had once been strong, it became increasingly silent in Indigenous affairs around Sydney. In the inner-city areas it was replaced by the streetwise, union-trained Indigenous voices that maintained strong links to areas such as Dubbo, Cowra and Moree. These same areas were strongholds of unionism

3 Eora peoples are loosely recognised as the traditional clans of the lands located between the Hawkesbury, Georges and Nepean Rivers. The southern Guringah (the Gai-mariagal) are included within the Eora distribution as they cover the Lane Cove River catchments, the northern side of Sydney Harbour and northern coastal suburbs. The word Eora, 'I-yora' or the many other forms of phonetic spelling, simply means people (Smith 2004). For the purposes of this paper Eora refers to the Indigenous custodians pre-contact within the Sydney geographic basin. The northern suburbs comprise the northern rim of that basin. 
within the shearing industry, which was the training ground for many iconic leaders of the Aboriginal resistance movement. This included Mr. Jack Patten, Mr. Bill Ferguson and Mr. William Cooper. The shearing industry and later the waterside industries were the schools for 19th and 20th century Aboriginal activists. The Eora peoples had little to no contact with unionism.

In time it appears respect for traditional custodianship was lost in the struggle for Aboriginal rights. This prolonged battle became too much for many of our Elders who we lost between the mid 1960s and the early 1970s. A power vacuum was created at a critical period. The new usurping black power brokers failed to recognise many of us with our fair skin and blue eyes. Whilst once we had shared our tables, our friendship and our land as Aboriginal peoples, many of us were now not black enough for the politically active. It was not until the late 1980s and early 1990s - during a period of increased understanding about the effects of government policies to biologically 'absorb' Aboriginal people into settler society - that we began to receive formal recognition once more as traditional custodians. Unfortunately this timing was inconvenient for some. It was then not in the best interests of some local Aboriginal land councils to recognise us. Indeed some took steps to exclude us from participating within 'their' organisations, that were first established to assist us.

The traditional owners of Sydney were 'black-washed' from the historical landscape. This was made clear to the writer and 80 other attendees and bystanders at a book launch at Gleebooks, Glebe on Tuesday 30 August 2005 when a heckler and a self-identified spokesperson for a Sydney Aboriginal land council boasted to the assembled group that 'they' (i.e. the Aboriginal land council) had proven that Colin Gale was not Aboriginal and that all other people who claimed to be of Darug descent were 'all liars'. When the writer questioned this elderly person as to his identity he stated that he was originally from Queensland. Further he added that as a member of the Sydney land council 'it' had the right to speak on Aboriginal issues as they were the 'real' Aboriginal people.

This illustrates the way in which land councils now assume the power and legal right to determine who is Aboriginal and who is not. This goes against the judgments of The Commonwealth $v$ Tasmania $[1983]^{4}$ and Gibbs $v$ Capewell [1983]. ${ }^{5}$ Neither individuals nor the New South Wales Aboriginal land council have the legal capacity to determine the Aboriginality of individuals or groups. It needs to be noted that Mr Colin Gale (on behalf of the Darug people) was unsuccessful in the Federal Court of Australia before Madgwick J on 31 March

4 The Commonwealth $v$ Tasmania 1983. 158 CLR 1, 274.

5 Gibbs v Capewell 1995. 128 ALR 577. 
2004 in a native title claim. ${ }^{6}$ Court records show this decision was based on Mr. Gale's contemporary way of life rather than his Darug descent. For example, 'Mr. Gale is living a suburban way of life indistinguishable from that of many non-Aboriginal Australians', and 'there is no evidence that there is now anything like a body of traditional laws and customs, having a normative content in relation to rights or interests in land, which any member of the claimant group now acknowledges or observes' ${ }^{7}$

The transcripts of this case have been carefully analysed. Mr Gales' Aboriginality was not in question. The claim made by the land council representative in Glebe on 30 August 2005 was misinformed and reflects the general attitude underlying attempts to usurp the rights and deny the existence of traditional owners. The LRA facilitates this process in its creation of New South Wales Aboriginal land councils.

The New South Wales land councils were established well before the landmark Mabo and Wik cases and operate in a fashion that has little in common with the objectives and practices envisaged by the Federal Court in the National Native Title Tribunal. However the New South Wales land councils have become cultural auditors through their recognition under State law. They deliver little if anything for the traditional people of the northern suburbs of Sydney as they are not recognised and are not admitted as members of an exclusive club composed of people from other Aboriginal nations. Many do not want to subject themselves to the same public humiliation administered to Mr Gale and do not register themselves on the Register of Native Title Claims. Further, many do not have the financial or political resources (or the family unity) to do so.

It is a matter of public record that the Minister responsible for native title utilises tactics that run dangerously close to an abuse of process against Aboriginal claimants. In the Winbar appeal Stein J remarked:

it is difficult not to feel some sense of intense surprise at the apparent conduct of the Minister and those who represent or assist him ... I do not make these remarks lightly since it is no pleasure to be critical of a Minister of the Crown. However, I find such conduct to be contrary to the spirit and intent of the Land Rights Act and particularly the recitals to the Act [8] (Chalk 1988b: 35).

The local Indigenous peoples of Sydney are aware that the Federal court is hostile. They have witnessed the loss of the Darug and they are all too aware of the opposition of the local Aboriginal land council, which is supported by State

6 Gale $v$ Minister for Land and Water Conservation for the State of New South Wales 2004, FCA 374 (31 March 2004).

7 Gale $v$ Minister for Land and Water Conservation for the State of New South Wales, ALR 2004: 8-9, lines 116, 121. Available at http://bar.austlii.edu.au/au/journals/AILR/2004/11.html, accessed 5 May 2007. 
legislation through the 1983 Act. The way in which the land rights system operates is difficult to both contest and accept on moral or legal grounds if you are a local, urban traditional owner.

The Hon Brad Hazzard has highlighted in 'parliamentary debate' that of the 130000 Aboriginal people in New South Wales less than 10 per cent are voting members of land councils (Legislative Assembly of New South Wales 2005: 17881) and 'many Aboriginal people ... are fed up to the back teeth with the failings in the Aboriginal land rights system. They are fed up with the fact that very few people in some land councils get the opportunity to benefit' (Hansard 2005: 17881). This Member of Parliament has raised two important issues; firstly, the poor representation of Aboriginal peoples in New South Wales land councils, and secondly, that only a few share the benefits.

To be a native title claimant in New South Wales you must successfully lodge a registration with the National Native Title Tribunal. In the registration process for native title, traditional owner groups require the support of their New South Wales land councils if they are to be successful native title claimants, otherwise the federal Minister could use the land council as an opposing body or land council members as opposing claimants. The urban traditional owner is in a perilous legal situation within an environment that is characterised by poor representation, poor delivery of benefits, poor administration, and a hostile federal Minister in the Native Title Court. It is important now to review some recent literature on Sydney and what constitutes an Aboriginal land council to ensure that the reader can begin to understand what New South Wales Aboriginal land councils are mandated to do and what is happening in Sydney.

\section{What constitutes an Aboriginal land council?}

It must be realised and accepted that the 1983 Act has not relieved the general poverty of New South Wales Aboriginal people. It has however been effective in delivering about 79000 hectares of land into the clutches of land councils since their inception. There are 122 local Aboriginal land councils in the State. In August 2004, 11 were under the control of a government-appointed administrator and the peak body, which had been operating under a cloud of accusations of financial and administrative mismanagement for several years, was also under the control of an administrator (Jopson and Ryle 2004: 30). From a series of reviews and inquiries, it is clear that New South Wales land councils have, since their inception, suffered 'problems with misappropriation and mismanagement' (Bayles in Chalk 1988a: 4)

When the 1983 Act was created, it did two things. First, it created a fund to finance the 122 local Aboriginal land councils by setting aside 7.5 per cent of all land tax collected for 15 years. Some of these funds were used to finance the land councils. The balance was set aside to provide funding for the future. When 
the scheme ceased in 1998, this fund amounted to approximately \$500 million. It was planned to pay a stipend to each council of around $\$ 110000$ per annum. Secondly, the new Act enabled the Indigenous people of New South Wales to claim any Crown land that was not needed for an essential public purpose. Local government councils resisted this move until 1991, when the peak body, the New South Wales Aboriginal Land Council, pointed out to them they could collect rate payments on any lands granted to local Aboriginal land councils. More than 2100 land claims have since been awarded to local Aboriginal land councils. This has made some of them very large property owners. This is particularly so for some operating along the coast and within the Sydney region. The Office of the Registrar of the Land Rights Act conservatively values these lands at $\$ 770$ million. The administrator of the New South Wales Aboriginal Land Council believes the figure could be closer to $\$ 3$ billion. These local Aboriginal land councils could collectively be a larger landowner than Lend Lease or Mirvac. Recent enquiries have revealed that a serious lack of necessary infrastructure has left the door open to corruption. One report makes the claim that land councils have been drawn into questionable dealings by lucrative offers from real-estate developers (Jopson and Ryle 2004: 30).

Many land councils are controlled by families and factional groups. Under the 1983 Act, a quorum of just 10 is needed for a legally constituted meeting. Of that number just eight can vote to legally approve a multimillion-dollar land sale (Jopson and Ryle 2004: 30).

There is little monitoring of the lands successfully claimed by local Aboriginal land councils and it is impossible to determine what lands they have inappropriately sold. Given their dealings are poorly monitored and are regularly conducted with little, or no, input or consultation with the traditional people of the lands in question, some of the coastal Aboriginal land councils' land sale dealings are of serious concern.

Individual members of land councils have publicly voiced their concerns about some of the mis-dealings that occur within their institutions (see e.g. Bayles in Chalk (1988a) quoted above). Other concerns include decision-making processes, powerful factions, and strivings for personal gain rather than the betterment of local Aboriginal people. For example, members have made the following claims which are not exhaustive. First, that notices of meetings are often 'tucked away' in obscure publications that most members never read. Secondly, powerful factions organise to meet alone and take various steps to prevent the attendance of others, so as to ensure voting delivers the outcomes desired by that particular group of members. Thirdly, most members of local Aboriginal community groups and councils are kept out of the 'deals' as they are not members of local Aboriginal land councils. While some make voluntary decisions not to associate with land councils, others are precluded on the basis that they do not meet the 
necessary criteria. The reasons for this exclusion are rarely disclosed. And finally, only a select few seem to receive any benefits from their membership of local Aboriginal land councils, be they financial or otherwise (Jopson and Ryle 2004: 30, 2004b: 31).

The 2001 census revealed that 135319 people living in New South Wales identified as Aboriginal (ABS 2002). Almost half of this group was living in financial stress. Most of them were existing on incomes classified as being below the poverty line. Almost one in five was unemployed and one-third lived in sub-standard housing. Of the 135319 Aboriginal people in the State, only 20459 or 15 per cent are members of Aboriginal land councils (Jopson and Ryle 2004a: 30). As previously mentioned, the logical deduction is that the great majority of Aboriginal people in the State are not receiving any flow-on benefits from the 1983 Act. Despite their chronic poverty, they have not received any benefit from the 79000 hectares of land granted to Aboriginal people or the sale of prime coastal property by Aboriginal land councils.

Land lies at the heart of Indigenous cultural heritage. If the land is being managed (and sold) by a small minority of Aboriginal people who have no historical connections with that land - be they spiritual, cultural, intellectual, ceremonial or economic - then surely the claim can be made that the New South Wales Aboriginal land councils are little more than real estate speculators. They are by their own actions usurpers.

\section{The Sydney experience}

In March 2003 an investigator revealed the Sydney based local Aboriginal land council was bordering on mismanagement and it faced the risk of losing its land bank which had been built up through years of government grants. He concluded that this Aboriginal land council's 'adherence to standard corporate governance procedures was almost non-existent' (Robert Jackson, cited in Jopson 2003a). It would appear that responsible fiduciary management was not evident.

Just prior to this investigation, this Aboriginal land council had sold five parcels of land, which collectively were valued conservatively at over \$13 million. They were located at Belrose, Terry Hills, Frenchs Forest and Asquith. All of this land lies within Guringah language borders. So too do the following properties that they allegedly hold (if they have not already sold them):

- 17 Belrose parcels valued at $\$ 22$ million

- 9 Cromer parcels worth $\$ 18.5$ million and

- 6 Terry Hills parcels estimated at $\$ 4.5$ million (Jopson 2003b).

When Sydney Morning Herald reporter Debra Jopson interviewed the former chairperson of this Aboriginal land council, she was advised the land sales were necessary to ensure the economic self-sufficiency of the council, as it was 
land-rich but cash-poor (2003b). In other words, land had to be sold to keep the body financial. For all accounts and purposes, this appears to be an unfinancial organisation with almost non-existent corporate governance procedures (Jopson 2003a). The sale of Aboriginal land goes against the very ethos of Aboriginal peoples' struggle since colonisation, which is the fight to preserve and maintain Aboriginal land.

The investigator also noted the cash blowouts in this council's current expenditure. For example, their forward commitments at the time were budgeted at approximately $\$ 2.5-\$ 2.8$ million. There was however, only $\$ 2.4$ million in the term deposit account, which was supposed to earn sufficient interest to fund running costs. The council would therefore have to withdraw its term deposit to fund these running costs. This would then deprive it of future interest and result in still further land sales to enable the ongoing life of the organisation (Jopson 2003a).

It seems the council will have to continue to sell land to fund the administration of this organisation. This raises important questions. Firstly, where is the money going? Secondly, what are the details of the successful projects this organisation espouses? Thirdly, how long will this be allowed to continue?

The land bank is limited. The cultural heritage landscapes that the Aboriginal land councils are selling are irreplaceable. Yet land councils continue to sell land to meet operational expenses.

These land sales are being carried out with total disregard for the spiritual/cultural importance of this land to local Aboriginal people and traditional 'owners'/custodians. There is no consultation; the land is being treated like a common chattel. It is being sold with contempt for the traditional Indigenous belief that we do not own the land, the land owns us. We ask, how can they be permitted to continue to sell off our Mother earth?

If Guringah people went to Cowra, Dubbo or Moree and began to sell land there in much the same way as the executive of the Sydney-based land council is doing, there would be a major outcry. Yet in Sydney the usurpers have successfully stifled the voice of the traditional 'owners'/custodians. It is important to understand how they have managed to achieve this.

The Aboriginal land council executive have declared that the local traditional 'owners' are extinct and have disseminated this mistruth through their extensive networks within the New South Wales National Parks and Wildlife Service, Local Government Councils situated on Guringah lands, and various other government departments and agencies. This is, however, in sharp contradiction to their public relations material. For example, one public notice makes the claim that 'contrary to white propaganda the original inhabitants, the Eora people, were not wiped out after the European invasion' (Madden 2000). Yet a letter 
from their former Chairperson dated 18 March 2003 addressed to the General Manager and Mayor of the North Sydney Council, and copied to eight other local government councils (Lane Cove, Hornsby, Kuring-gai, Willoughby, Mosman, Manly, Warringah and Pittwater Councils) declared it was 'unaware of any traditional owners of the North Shore Peninsula'. This is incorrect, for a simple membership check of the Registrar of Aboriginal Corporations ICN 4270 reveals Guringai Tribal Link Aboriginal Corporation incorporated on 11 August 2003. Their list of members are Guringai people (other spelling Guringah) or they identify as descendents of Guringah people. The claim of the Aboriginal land council in question, as to the existence or non-existence or traditional owners is unfounded and misleading to the public.

This same Sydney Aboriginal land council had previously communicated with the writer on the basis that I was then recognised as a traditional custodian. Ironically, the State's Governor General, Attorney General and Minister for National Parks and Wildlife, and the Royal Society for the Arts all formally acknowledge the writer as a member of the Guringah people. So likewise do countless numbers of professional people, organisations, Indigenous groups and other individuals. The local Aboriginal land council, however, continues to state it is unaware of any traditional owners when it is convenient for them to do so.

Its actions in managing the recent burial of human remains on North Head on March 4, 2005 typifies the land council's contempt towards Aboriginal people outside of its own circle of direct influence. The media and a select group of Aboriginal people were advised when and where the burial was to occur, and invited to attend. The Indigenous heritage staff of the overseeing government department omitted to invite the local Aboriginal community or relatives of the deceased. No Guringah persons were invited despite numerous telephone calls to the New South Wales National Parks and Wildlife office and the Australian Museum staff by the writer. It is difficult to explain the pain of being deliberately excluded from the interment of your own ancestors; yet a further example of usurping.

These mixed public messages, questioning of Aboriginality and in some cases the denying of it without investigation or proof, in addition to limited membership and somewhat questionable management practices is a moral concern. In May 2004, the former NSW Minister for Aboriginal Affairs, Dr Andrew Refshauge, released a media statement that both admitted the NSW Aboriginal land council system was 'clearly not working well enough' and announced the establishment of a special taskforce to overhaul the system and fix fundamental problems (Refshauge 2004). Two issues papers have since been prepared by this taskforce. They go some way towards suggesting land councils have been given too loose a rein in the desecration of Indigenous cultural heritage 
through the sale of coastal ancestral lands to developers (NSW Aboriginal Land Rights Act Review Task Force 2005a, 2005b).

The control and power systems that the Aboriginal land councils enforce also have a direct influence on the cultural heritage industry, which needs to be reviewed, and a system of professional accreditation implemented. Presently qualifications and regulation is blurred as political correctness has reduced any form of questioning if a person of Indigenous heritage has the right to adopt/create or steal knowledge of an area and disseminate it. This problem was summed up by the well-known Indigenous businessman, Mr John Moriarty who at the time of writing is also a member of the National Indigenous Council. Mr Moriarty told me directly he was concerned with the 're-invention of Aboriginal knowledge' by Indigenous people who were not from Sydney who were developing their own agendas. ${ }^{8}$ It is important that only people of a professional, accredited standard be appointed as Cultural Heritage Officers. The ability to communicate the holistic knowledge and the cultural intricacies of particular lands calls for much more than just Aboriginal descent.

The legal implication regarding cultural heritage management entrusted to Aboriginal Land Councils who are usurping the resources of the traditional custodians is a concern if it affects Native Title decisions. If we review the Native Title Cases of Gale ${ }^{9}$ (2004 FCA 374) and Yorta Yorta ${ }^{10}$ (2002 194 ALR 534) the concept of what is tradition; (and it could be argued cultural heritage from the traditional custodian's perspective) reflects the fundamental nature of native title rights and interests. In many cases claimants will invite the Court to infer from evidence in the trial as to the content of traditional law and custom (s. 233 Yorta Yorta 2002). If usurping Aboriginal land councils have the legal position within NSW to dominate cultural heritage management practices then we are already experiencing a manifestation in the 'creation of culture' to earn income from property developers, the tourism industry and so on. This purported creation of culture by unsuitably qualified cultural heritage management staff will ensure conflicting information for the legal and anthropological professions to interpret and appraise. The 're-invention of Aboriginal knowledge' (Moriarty 2005) by Indigenous people who were not from Sydney who were developing their own agendas has the potential to distort or confuse at the very least, knowledge for the Native Title Courts.

\section{Conclusion}

The Land Rights Act 1983 (NSW) (as amended) and the subsequently established NSW Aboriginal Land Councils which are actively usurping the resources of

8 John Moriarty, pers. comm.. c. 2005.

9 Gale $v$ Minister for Land and Water Conservation for the State of New South Wales 2004. FCA374, 31 March 2004.

10 Yorta Yorta Aboriginal Community v Victoria 2002. 194 ALR 534. 
traditional owners/custodians in the sale of their land and control of cultural heritage matters are an impediment on the federal native title process.

Critics of the NSW Department of Aboriginal Affairs could also claim collusion and nepotism are rife within the land rights and cultural heritage systems and there is little monitoring to prevent it. At the present time many local Aboriginal land councils are closed shops, selling off lands and heritage for short-term profits. There is an urgent need for a bipartisan agreement in the NSW Parliament to amend the Act to remedy this situation; at the time of writing this paper the recent review does not facilitate this. Traditional 'owners'/custodians need to be included on the executive committee of local Aboriginal land councils. This should not be a token appointment, and if these have to be legislated then so be it. Perhaps this is where self-determination is not working when such actions need to be legally enforced. Indigenous people should be working together without division or hatred. There should be respect for country and its inhabitants. What has evolved in Sydney is shameful.

As Moreton-Robinson comments, 'questioning the integrity and legitimacy of Indigenous ways of knowing and being has more to do with who has the power and whether their knowledge is commensurate with the west's rational belief system' (2002: 3). The NSW Aboriginal land councils have power; this is undeniable under the 1983 legislation, and they have legitimacy within the west's belief system. It is time that this power was dissipated into socially accepted interaction; we could do so much more working together in lieu of faction fighting.

There is need for a sale register to be lodged with the NSW Department of Aboriginal Affairs and maintained on an ongoing basis to protect the interests of the greater majority of NSW Indigenous people who are not members of Aboriginal land councils. All sales should be vetted by the Minister. This is not to take opportunities for self-determination away from Aboriginal people. Rather it is a necessary measure to protect the majority of Aboriginal people from the questionable actions of an enterprising few. This would ensure the cultural heritage of local Aboriginal people and traditional 'owners'/custodians are not sold from underneath them.

Under Australian trust law, the following three institutions have a fiduciary responsibility to Aboriginal 'owners'/custodians: the NSW Government, the executive of local Aboriginal land councils, and local government authorities within which Aboriginal land councils operate. Each has an important responsibility to remedy this situation before all of the land has been sold and the proceeds squandered.

The 1983 Act was purportedly established to improve the living conditions and life-chances of Aboriginal people in New South Wales and redress some of the hardships they have suffered as a direct result of their dispossession from their 
ancestral lands. The Act has now become less effective in achieving these aims. It needs urgent revision to correct the current injustices being experienced by some Aboriginal people in New South Wales. The recent amendments and review do not appear to have resolved the concerns expressed above.

In conclusion, Aboriginal people have suffered much over the generations; let us no longer continue to suffer, rather let us work together for the betterment of our people. This is my wish. Native title is a dream to the urban Koori; the Act effectively stole 25000 acres of trust land away from Koori people and has given us 24 years of turmoil and hate. It is time to correct these issues and for Koori people once again learn to respect one another and live together as one in Eora pemul.

\section{Acknowledgments}

A version of this paper was presented at the 'Effects of Native Title Workshop', Old Canberra House, The Australian National University, Canberra, November $1-2,2005$. Special thanks go to the organising committee of CAEPR and the financial support of AIATSIS and CAEPR to run the two day seminar. Special thanks also go to Professor Mick Dodson of the National Centre for Indigenous Studies for his support in allowing me to attend the workshop, to Dr Benjamin Smith for inviting me, to Professor Peter Read (a true warrior in the struggle for equity and peace for Aboriginal people), to the staff of CAEPR (particularly Professor Jon Altman for his inspiration and support), to various Federal and State Members of Parliament, local Mayors and Local Government staff, together with a long list of historians, anthropologists and archaeologists; in addition to staff within museums and the NSW National Parks and Wildlife Service for their moral support in a battle that seems to have no ending (their privacy is maintained due to their fears of recrimination), and the Indigenous inhabitants of the Northern Suburbs of our land, especially Ms Susan Moylan-Coombs for her untiring support. Di-goori goor to my Guringah family for their voice and prayers, and to the various church leaders and their congregations of the Northern suburbs for their spiritual support in this struggle.

I would like to thank participants at the workshop for their helpful feedback as it surprised me to learn that our people were not the only ones who were being denied their heritage by other Indigenous usurpers who were in control of the very organisations that were set up to protect our culture.

My special thanks also go to Jill Barnes for her editorial eye and untiring enthusiasm while reading and commenting on my work. 


\section{References}

Australian Bureau of Statistics (ABS) 2002. Australian Social Trends 2002, available at <http://www.abs.gov.au/>, accessed 11 May 2007.

Bayles, T. 1988. 'The NSW Land Rights Act', Interview, Radio 2BL, 12 April 1988.

Bennett, S. 1999. White Politics and Black Australians, Allen and Unwin, St. Leonards.

Brook, J. 1999. Shut Out from the World: The Hawkesbury Aborigines Reserve and Mission 1889-1946, Deerubbin Press, Berowra Heights, NSW.

Chalk, A. 1988a. 'The NSW Land Rights Act: Interview with Tiga Bayles,' Aboriginal Law Bulletin, 21 (2): 1-2. Available at <http://kirra.austlii.edu.au/au/journals/AboriginalLB/1988/21.html>, accessed 11 May 2007.

Chalk, A. 1988b. 'NSW Land Rights: All Just an Act?' Aboriginal Law Bulletin. 30 (2): 32-8.

Foley, D. 2001. Repossession of Our Spirit, Aboriginal History, Canberra.

Goodall, H. 1988. 'Aboriginal calls for justice: learning from history', Aboriginal Law Bulletin, 37 (2): 33-8.

Goodall, H. 1996. Invasion to Embassy: Land in Aboriginal Politics in New South Wales, 1770-1972, Allen and Unwin, St. Leonards.

Horner, J. 2004. Seeking Racial Justice: An Insider's Memoir of the Movement for Aboriginal Advancement, 1938-1978, Aboriginal Studies Press, Canberra.

Jopson, D. 2003a. 'Report warns land council property bank is running out', The Sydney Morning Herald, July 7. Available at $<$ http://www.smh.com.au/cgi-bin/common/popupPrintArticle.pl?path+articles/2-003/>. Accessed 19 January 2004.

Jopson, D. 2003b. 'Metro land council claims million-dollar stake in the northern suburbs', The Sydney Morning Herald, March 7. Available at $<$ http://www.smh.com.au/cgi-bin/common/popupPrintArticle.pl?path+articles/2-003/>. Accessed 19 January 2004.

Jopson, D. and Ryle, G. 2004a. 'A gift with strings attached', The Sydney Morning Herald, 31 July: 30.

Jopson, D. and Ryle, G. 2004b. 'Black land white shoes', The Sydney Morning Herald, 31 July: 23.

Legislative Assembly of New South Wales 2005. New South Wales Aboriginal Land Council Management', Hansard, 15 September 2005: 17881. 
Madden, A. 2000. 'The art community and the Sydney Metropolitan Land Council', ARTnews, April 2000. Available at <http:/www.artnews.com.au/madden.htm>. Accessed 14 January, 2004.

Moreton Robinson, A. 2002. 'I still call Australia home', in S. Ahmed and M. Sheller (eds), Uprootings/Regroundings, Berg, London.

New South Wales Aboriginal Land Rights Act Review Task Force. 2005a. Review of the Land Dealings Provisions of the Aboriginal Land Rights Act 1983, Issues Paper 1, August 2005, NSW Department of Aboriginal Affairs, Sydney.

New South Wales Aboriginal Land Rights Act Review Task Force, 2005b. Structure, Representation, Governance and Benefits, Issues Paper 2, November 2005, NSW Department of Aboriginal Affairs, Sydney.

Nugent, M. 2005. Botany Bay Where Histories Meet, Allen and Unwin, Crows Nest, NSW.

Refshauge, A. 2004. 'Overhaul to NSW Aboriginal Land Council system', Media Release by Deputy Premier, Minister for Education and Training, Minister for Aboriginal Affairs:, 26 May.

Smith, K. 2004. Language of Port Jackson and Coastal Sydney in Eora Clans, MA Thesis, Macquarie University, Sydney.

Wikipedia Encyclopedia 2007. 'Native title'. Available at $<$ http://en.wikipedia.org/wiki/Native_title>. Accessed 17 May 2007.

Wilkie, M. 1985. Aboriginal Land Rights in NSW, Alternative Publishing Cooperative, Sydney. 